\title{
Daniel mellem to verdener: Diasporamotiver i Daniels Bog 1-6
}

\author{
Adjunkt, dr.theol. \\ Frederik Poulsen, Københavns Universitet
}

\begin{abstract}
The book of Daniel is set in the diaspora. As a Jew in Babylon, Daniel exists between two worlds: the culture of the host land and the values of his ancestral land. This article focuses on the tension between these two in the court legends (chs. 1-6). I argue that the relation between the two worlds is a dynamic one that is construed differently in the single stories. In my reading of the six stories, I demonstrate that the consistent use of irony, satire, and utopia points to a fundamental ambiguity of diasporic existence.
\end{abstract}

Keywords: The book of Daniel - court legends - diaspora - satire - Jewish religion - acculturation - resistance

\section{Indledning}

Vi kender alle fortællingen om Daniel, der tvinges til at tilbringe en nat $\mathrm{i}$ en hule med glubske løver. ${ }^{1}$ Men hvorfor ender den fromme drømmetyder egentlig dér? Og hvad kan de nærmest eventyrlige fortællinger om Daniel og hans venner i Babylon sige om livet som jøde $i$ et fremmed land?

Daniels Bog består af en fascinerende blanding af legender og visioner. ${ }^{2}$ Fortællingerne i kapitel 1-6 beretter om fire jøders oplevelser ved det babylonske hof, mens visionerne i kapitel 7-12 forudsiger dagenes ende og den store kosmiske kamp mellem jordiske konger og himmelske hærskarer. I begge dele af bogen er hovedpersonen spændt ud mellem to verdener. I bogens anden halvdel sker det i form af apokalyptikkens markante dualisme mellem himmel og jord, hvor Daniel gennem syn og drømme får adgang til himmelske hemmeligheder om verdens undergang og gudsrigets komme. I bogens første del, som jeg behandler i denne artikel, er Daniel som jøde i det fremmede

1. Denne artikel er udarbejdet under forskningsprojektet "Stories in a Strange Land", der er støttet af Carlsbergfondet.

2. For en indføring i Daniels Bog, se Sif Egede, "Daniels Bog: Vise mænd og tvivlsomme konger", Gud og os - teologiske lasninger af Det Gamle Testamente i det 21. århundrede, red. Anne Katrine de Hemmer Gudme \& Jan Dietrich (København: Det Danske Bibelselskab) (under udgivelse). 
også spændt ud mellem to verdener, nemlig mellem sit jødiske ophav og den nye virkelighed i Babylon. Det er et grundvilkår for ethvert diasporasamfund.

\section{Daniels Bog 1-6 og den jødiske diaspora}

Fortællingerne om Daniel i Babylon er som udgangspunkt diasporalitteratur. Der er en række litterære, genremæssige og tematiske ligheder med andre bibelske fortællinger om jøder i det fremmede: Josef og hans brødre i Egypten samt Ester og Mordekaj ved det persiske hof. ${ }^{3}$ Men hvor den mere novelleagtige litteratur om Josef og Ester har et tydeligt fremadskridende plot, så fremstår første halvdel af Daniels Bog nærmere som en antologi af enkeltstående historier eller legender. ${ }^{4}$

Daniels Bog 1-6 begynder med den babylonske konge Nebukadnesars erobring af Jerusalem og slutter med indsættelsen af perserkongen Kyros. Selvom vi har at gøre med en samling af enkeltscener eller tableauer, der på forskellig vis skildrer livet ved det fremmede hof, er der alligevel nogle fællestræk. To af dem handler om udfrielse, hvor først vennerne reddes fra ildovnens flammer (kap. 3) og siden Daniel fra løvekulen (kap. 6). De fire jøder indgår i begge historier i en konflikt med hoffets øvrige ansatte. Tre af de andre fortællinger er tydningshistorier, hvor Daniel udlægger Nebukadnesars drømme om statuen (kap. 2) og verdenstræet (kap. 4) samt skriften på væggen under efterfølgeren Belshassar (kap. 5). Daniel indgår ved disse lejligheder i en konkurrence med kongens andre rådgivere om at løse opgaven. Perspektivet skifter således mellem de fire jøder og kongen. ${ }^{5}$ I tre af historierne (kap. 1, 3 og 6) er Daniel og vennerne i centrum og står i en identitetsmæssig konflikt mellem kongens krav og deres

3. Fx Ludwig A. Rosenthal, "Die Josephgeschichte, mit den Büchern Ester und Daniel verglichen", $Z A W 15$ (1895), 278-284; Lawrence M. Wills, The Jew in the Court of the Foreign King: Ancient Jewish Court Legends, HDR 26 (Minneapolis: Fortress Press 1990); Matthew Michael, "Daniel at the Beauty Pageant and Esther in the Lion's Den: Literary Intertextuality and Shared Motifs between the Books of Daniel and Esther", OTE 29 (2016), 116-132.

4. Til denne legendetradition hører også de apokryfe tilføjelser til Daniels Bog, navnlig fortællingerne om Susanna og Bel og dragen; se Jesper Høgenhaven, "Den græske Daniel”, Tradition og nybrud. Jødedommen i hellenistisk tid, red. Troels Engberg-Pedersen \& Niels Peter Lemche, FBE 2 (København: Museum Tusculanums Forlag 1990), 141-151.

5. Naama Golan, "The Daniel Narratives (Dan 1-6): Structure and Meaning”, JHS 19 (2019), 1-24. 
religiøse traditioner (mad, tilbedelse, bøn). I de tre andre (kap. 2, 4 og 5) er kongen selv i centrum og hans manglende underkastelse for den himmelske hersker.

Dele af fortællingerne kan være blevet til allerede i eksiltiden under babylonerne, dvs. i 500-tallet f.Kr. Deres nuværende form bærer dog præg af at være blevet omarbejdet og udvidet i persertiden og frem til hellenistisk tid. Det er sandsynligt, at nogle af dem til at begynde med har eksisteret uafhængigt af hinanden. Senere er de blevet samlet, muligvis først i mindre samlinger, og ordnet efter rækkefølgen af hedenske konger. ${ }^{6}$ Legendesamlingen om drømmetyderen Daniel er siden blevet bragt til Jerusalem og har her dannet grundlag for visionerne i bogens anden halvdel, hvoraf hoveddelen stammer fra krisen under makkabæerne i 160'erne f.Kr. De fleste forskere regner nemlig med, at fortællingerne om de fire jøder i Babylon oprindeligt er opstået i selve diasporaen. De tidlige jødiske diasporasamfund blev, så vidt vi kan vurdere, primært etableret efter babylonernes ødelæggelse af Jerusalem i begyndelsen af 500-tallet f.Kr. Mange indbyggere flygtede fra invasionshæren til de nærliggende områder, herunder Egypten; andre blev ført bort til Babylon. Når det gælder Daniels Bog 1-6, antager de fleste forskere, at fortællingerne er blevet til i den østlige diaspora. Til gengæld er der stor diskussion om, hvilket syn på diasporatilværelsen der kommer til udtryk i dem: åbenhed eller modstand?

På den ene side har man påpeget en relativ positiv skildring af diasporaen som et sted fuld af muligheder for rigdom og succes. Daniels Bog 1-6 illustrerer angiveligt en særlig "livsstil" for jøder i det fremmede. ${ }^{7}$ Daniel er rollemodellen, der ved dygtighed, loyalitet og åbenhed over for værtslandet skaber en enestående tilværelse ved det babylonske hof. Det er tilsyneladende muligt at forene jødisk religion og kultur med engagement i et ikke-jødisk samfund. Fortællingerne kan dermed historisk afspejle en veluddannet jødisk overklasse, der med Daniel som "træningsmanual” stræber efter at gøre karriere i magtens centrum.

På den anden side har andre understreget fortællingernes karakter af "modstandslitteratur", der løbende kritiserer det fremmede styre og

\footnotetext{
6. En af vanskelighederne består $i$ at forklare den besynderlige blanding af tekster på hebraisk $(1,1-2,4 \mathrm{a} ; 8,1-12,13)$ og aramæisk $(2,4 \mathrm{~b}-7,28)$. For nyere teorier om tilblivelsen af Daniels Bog, se John J. Collins, Daniel: A Commentary on the Book of Daniel, Hermeneia (Minneapolis: Fortress Press 1993), 24-38; Carol A. Newsom (with Brennan W. Breed), Daniel: A Commentary, OTL (Louisville: Westminster John Knox Press 2014), 6-12.

7. W. Lee Humphreys, "A Life-Style for Diaspora: A Study of the Tales of Esther and Daniel”, JBL 92 (1973), 211-223.
} 
forudsiger dets undergang. ${ }^{8}$ Hoffet er ikke kun et sted for lykkeriddere. Det er beskidt og konfliktfyldt, præget af intriger og magtmisbrug. Fortællingerne afspejler dermed ikke en privilegeret overklasses bekvemme tilværelse i det fremmede, men en underkuet minoritet og dens oplevelser af forfølgelse og fremmedgørelse. At Daniel igen og igen fastholder sin jødiske kultur og religion på trods, tjener netop til at styrke den fælles samhørighed blandt en etnisk gruppe, der er truet på livet. Jøden Daniels succes ved hoffet kunne således være underklassens drømme om, hvordan verden kunne se ud.

At fortællingerne om Daniel og vennerne også handler om at modstå et fremmed herredømme, ses i deres litterære form. Flere af dem er samfundssatire, der med grove overd rivelser og humor manipulerer med opfattelsen af hoffet, midtpunktet for magtudøvelse. ${ }^{9}$ Latterliggørelsen af kongen er et gennemgående træk. Overdrivelserne står i kø: regentens ustyrlige vrede, størrelsen på festerne og på belønningerne for at tyde de mystiske meddelelser samt hedenske konger, der ærer og lovpriser Daniels Gud. Det gælder også en række fantasifulde træk: en menneskefortærende ovn af flammende ild, en konge, der forvandles til et dyr, en gådefuld indskrift på væggen og en grav fuld af glubske løver. Endelig fremstår de fleste af figurerne som rene karikaturer: Daniel og vennerne er de fromme, veluddannede og ydmyge helte, der ikke kan sætte en fod forkert; kongerne er utilregnelige, ondskabsfulde og manipulerbare; og hoffets øvrige ansatte er dumme og uduelige.

Fortællingernes karakter af velskrevet litteratur har væsentlige konsekvenser for læsningen. ${ }^{10}$ For det første fremstiller de en fiktiv verden, der ikke entydigt siger noget om deres socialhistoriske baggrund. Vi kan ikke ud fra fortællingernes litterære univers slutte, hvem der har skrevet dem og under hvilke vilkår. For det andet tager fortællingerne del i en udbredt interesse i antikken for det spændingsfyldte, intrigante og eksotiske liv ved kongens hof. Vi ved ud fra egyptiske, mesopotamiske og græske paralleller, at det var en populær genre, datidens House of Cards, og i fortællingerne om jøderne ved det babylonske hof må vi derfor forvente nogle bestemte, stereotype træk, som hører til denne genre (Collins 1993, 44). Man kan med rette spørge,

8. Daniel L. Smith-Christopher, "Prayers and Dreams: Power and Diaspora Identities in the Social Setting of the Daniel Tales", The Book of Daniel: Composition and Reception, Volume 1, red. John J. Collins \& Peter W. Flint, VTSup 83,1 (Leiden: Brill 2001), 266-290.

9. David M. Valeta, "Court or Jester Tales? Resistance and Social Reality in Daniel 1-6”, PRSt 32 (2005), 309-324.

10. Mattias Henze, "The Narrative Frame of Daniel: A Literary Assessment", JSJ 32 (2001), 5-24. 
om Daniels Bog 1-6 handler mere om livet ved hoffet end om livet i diasporaen. Dette er dog ikke et enten-eller, for i den litterære iscenesættelse af det fremmede hof flyder de to sammen som et billede på fordele og farer ved at opholde sig uden for det oprindelige hjemlands grænser.

Efter min mening kan første halvdel af Daniels Bog læses som tekster, der i fortællingens form behandler nogle grundlæggende spørgsmål ved tilværelsen i diasporaen. ${ }^{11}$ Daniel og hans venner lever som jøder i det fremmede mellem to verdener. Som diasporasamfund er de spændt ud mellem hjemlandets værdier og det nye lands majoritetskultur. Den rette balance mellem afsondring og assimilation er til stadig forhandling. Isolerer de sig for meget, kan de blive opfattet som fjendtlige over for værtskulturen. Tilpasser de sig for meget, er de i fare for at miste deres særegne kulturelle identitet. Daniel og hans venner skal på en og samme tid indordne sig og modstå det fremmede herredømme. De skal bevare deres jødiske tradition i en ikke-jødisk verden. Det er en stadig blanding af loyalitet over for styret og benhård kritik af dets overgreb.

I den følgende læsning af Daniels Bog 1-6 vil jeg have fokus på denne spænding. Mit udgangspunkt er, at forholdet mellem de to verdener er dynamisk og iscenesættes forskelligt igennem de enkelte fortællinger. Det er netop i nuancerne, i ironien og i utopien, at diasporalivets tvetydigheder viser sig.

\section{Daniel 1,1-21: En trojansk hest i Babylon}

Kapitel 1 udgør en generel indledning til Daniels Bog. Vi får en præsentation af hovedkaraktererne, baggrunden for Daniel og vennernes ophold i Babylon, en tidsramme og en beskrivelse af det fremmede hof, hvor de følgende begivenheder udspiller sig.

Vers 1-2 sætter rammen for bogens begivenheder, i stil med de små indledningsafsnit i den historiske litteratur (fx 2 Kong 24,1; Jer 39,1). Kong Nebukadnesar erobrer Jerusalem og fører guld- og sølvkarrene fra Guds tempel til sin egen guds skatkammer hjemme i Babylon. Angrebet på Jerusalem angives til Jojakims, Judas konges, tredje re-

11. Jf. Mark J. Boda, "Identity in Diaspora: Reading Daniel, Ezra-Nehemiah, Esther as Diasporic Narratives", Rejection: God's Refugees in Biblical and Contemporary Perspectives, red. Stanley E. Porter (Eugene: Wipf and Stock 2015), 1-26; Jill Middlemas, "Biblical Case Studies of Diaspora Jews and Constructions of (Religious) Identity", Religion in Diaspora: Cultures of Citizenship, red. Jane Garnett \& Sondra L. Hausner (Basingstoke: Palgrave Macmillian 2015), 36-54. 
geringsår, dvs. 605 f.Kr. Denne oplysning er ikke historisk pålidelig, men kan afspejle Krønikebøgernes omtale af Jojakims eksil og bortførelsen af tempelkarrerne (2 Krøn 36,6-7). Historisk set fandt babylonernes første belejring af Jerusalem først sted i 597 f.Kr.

Indledningsversenes egentlige funktion er dog med dette sviende nederlag at sætte stemningen for bogen som helhed. Afsættet for Daniel og hans venners tilstedeværelse i Babylon er i et diasporaperspektiv dybt traumatisk, og til trods for deres strålende succes ved det babylonske hof fastholdes deres identitet som bortførte jøder gennem hele fortælleforløbet $(2,25 ; 5,13 ; 6,14) .{ }^{12}$ De er ofre for en brutal ødelæggelse af slægtens gamle hovedstad og lever i det fremmede på værtslandets nåde. Bortførelsen af tempelkarrene - symbolet på Guds beskyttende nærvær - er ikke bare en grufuld profanering af det hellige tempel i Jerusalem, men også et tegn på jødernes tab af kulturel uafhængighed. De hellige kar står nu i en babylonsk guds tempel! Jøderne er afskåret midtpunktet for deres religiøse liv, templet og dets inventar, og må i det fremmede udvikle nye praksisformer.

De to første vers rummer ikke desto mindre nogle antydninger af, at overgivelsen til en fremmed magt ikke er altopslugende (Valeta 2005, 317). For det første er begivenhederne for hele bogen styret af jødisk tidsregning, Jojakims regeringsår, til forskel fra tidsangivelserne i resten af bogen, som følger de fremmede konger. ${ }^{13}$ For det andet siges det udtrykkeligt, at Herren, jødernes Gud, har givet Nebukadnesar magten over sit folk og dets ejendom. Babylonernes konge er blot hans redskab, og Gud giver, som det senere pointeres, magten til, hvem han vil. Tabet af Jerusalem er ganske vist et nederlag, men det er det erobrede folks egen Gud, der i virkelighed står bag. Tilværelsen i det fremmede er villet af Gud, og han har stadig magten.

Daniel og hans venner tilhører gruppen af smukke og talentfulde unge mænd fra den jødiske overklasse. I lyset af deres unge alder må de forventes dels at føle sig mindre tilknyttet til deres oprindelige hjemland end den ældre generation af deres landsmænd, dels at være mere åbne over for at gribe mulighederne i det nye land. Den oplæring til embedsmand, som Nebukadnesar giver sin hofchef Ashpenaz ansvar for, handler om mere end tilegnelsen af færdigheder i administrationen. Den har på et dybere plan karakter af en indoktrineringsproces, der i løbet af tre år skal udslette jødernes etniske og kulturelle

12. Ligesom praktisk talt alle ældre og nyere fortolkere af Daniels Bog antager jeg, at Daniel og hans venner ifølge bogens eget litterære univers blev født i Jerusalem og skal regnes blandt den gruppe af jøder, som Nebukadnesar efter erobringen af byen har ført med sig til Babylon (jf. 1,2).

13. Dan 1,$21 ; 2,1 ; 7,1 ; 8,1 ; 9,1 ; 10,1 ; 11,1$. 
særkende - sprog, mad, identitet - og forvandle dem til kongetro "babylonere" (jf. Esters forvandling til persisk dronning i Est 2).

Kaldæernes skrift og tungemål, som de skal undervises i, handler ikke kun om sprog. Der er tale om tilegnelsen af en specifik babylonsk visdomstradition, der som kulturel kode står i modsætning til den tilværelsestydning, som de har med hjemmefra (Newsom 2014, 44-45). Den daglige modtagelse af mad og vin fra Nebukadnesars bord handler ikke kun om ernæring, men også om underkastelse under babylonernes herredømme. Ashpenaz' tildeling af babylonske navne til de unge jøder understreger den tilsigtede identitetsmæssige forvandling (jf. navngivningen af Josef i 1 Mos 41,45). Daniel får navnet Beltshassar.

Navngivningen er samtidig et vendepunkt, for i Daniels svar begynder en skjult modstand at vise sig. ${ }^{14}$ Han beslutter i sit hjerte, i sit allerinderste, at han ikke vil gøre sig selv uren ved kongens mad og vin. I forskningen er der forskellige opfattelser af Daniels motiver for at afvise kongens forplejning. Det gælder både forståelsen af "at være

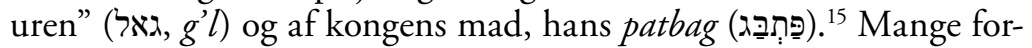
tolkere ser en henvisning til diasporajøders forbud mod at nyde fremmed og derved uren mad og vin; så skrappe "spiseregler" er dog ikke bevidnet i andre af samtidens tekster. ${ }^{16}$ Denne tolkning er ikke nødvendigvis forkert, men kan heller ikke stå alene. For Daniels modvilje mod at gøre sig selv uren spejler sig netop i templets ødelæggelse og karrenes forflyttelse til fjendens land. Tempelkarrene er blevet urene, underlagt babylonernes magt. På et personligt plan søger Daniel at modstå presset for, at det samme skal ske for ham: At han under optræningen ved hoffet skal blive underlagt og fuldstændigt assimileret ind i værtslandets kultur.

Den urenhed, som Daniel søger at undgå, er i andre tekster forbundet med blod (Es 59,3; 63,3; Klages 4,14). Det kunne tyde på, at kongens patbag mere konkret består af kød. Til støtte for denne tolkning

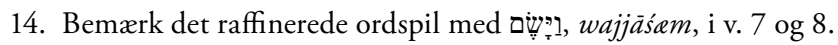

15. Se Anne E. Gardner, "The Eating of 'Seeds' and Drinking of Water by Daniel and Friends: An Imitation of Holiness", ABR 59 (2011), 53-63.

16. I Esters Bog er der til sammenligning ingen betænkeligheder ved at indtage mad og vin ved det persiske hof. Først i Septuaginta, i den senere hellenistisk-jødiske genskrivning af fortællingen, optræder bordfællesskabet med ikke-jøder tilsyneladende som et problem. I sin store bøn, som ikke findes i den hebraiske udgave af fortællingen, forsikrer Ester Gud, at "din trælkvinde har ikke spist ved Hamans bord, jeg har ikke kastet glans over kongens gilde og ikke drukket offervin" (TilfEst C,28). I andre græsksprogede diasporafortællinger skærpes opmærksomheden på mad og drikke også: Tobit vogter sig for at spise samme mad som hedningerne (Tob 1,10-11; jf. 1 Makk 1,62-63), og i assyrernes lejr insisterer Judit på at spise sin medbragte mad (Judit 12,2). 
er, at Daniel og hans venner i en prøveperiode på ti dage vil nøjes med korn eller grøntsager (זֵרעצים, zero'îm) og vand. Da tilsynsmanden siden sammenligner de fire jøder med andre unge mænd, der har spist og drukket fra kongens bord, er Daniel og vennerne ironisk nok

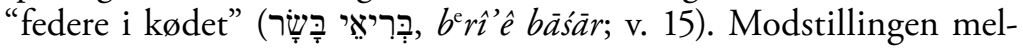
lem kød-vin og grøntsager-vand spiller især på modsætningen mellem kulturens forarbejdelse og naturens egne frembringelser. ${ }^{17}$ Det er netop babylonernes profane kultur og dens produkter, tilberedt kød og vellavet vin, som Daniel modstår. Det samme gælder kilden til hans suveræne forstand. Den kommer ikke fra den tillærte babylonske lærdomstradition, men fra Gud selv, der i det skjulte giver Daniel og vennerne alverdens indsigt og visdom.

Højdepunktet indtræder ved Nebukadnesars afsluttende bedømmelse af alle de unge mænd. For ingen er som Daniel og hans tre venner. De fremstår ti gange klogere end alle tænkelige vismænd i riget, og de får straks tildelt en stilling. Ironien er tyk. De fire mænd, der mest konsekvent har modsat sig den kongelige indoktrinering, kommer til at tjene kongen! Det er tydeligvis en satirisk pointe, at kongen ikke aner, hvad der foregår. Han har ikke kendskab til deres alternative kost gennem de tre år. Han har ikke kendskab til deres egentlige kilde til indsigt. For hans blik fremstår de derimod som ypperlige eksperter i babylonsk visdom, som med nye navne og understøttelse fra hans bord er klar til at virke som loyale embedsmænd. I virkeligheden er Daniel og vennerne nærmere en trojansk hest, der i det ydre ser indbydende og uskadelig ud, men som i det indre rummer kimen til modstand.

Kapitel 1 spiller i sin helhed på forholdet mellem to virkeligheder, en ydre og en indre, en babylonsk og en jødisk, en jordisk og en himmelsk. I det ydre er Daniel og hans venner oplært i babylonsk kultur, men i det skjulte fastholder de deres egen kultur i form af åbenbaringer fra deres fædres Gud. I det ydre optræder Daniel som babyloneren Beltshassar, men det er kun kongen, som bruger dette navn $(4,6.15)$. Tilsyneladende forsyner de fire jøder sig fra kongens bord, men i al hemmelighed forbliver de uafhængige af hans indflydelse. I det ydre tjener de Nebukadnesar, men i virkelighed tjener de Gud, Himlens Herre. Denne modstilling af to virkeligheder flugter med åbningsversenes påstand om, at i det ydre står Nebukadnesar, jordens mægtigste mand, bag erobringen af Jerusalem, men i det skjulte handler den, der har magten over historien.

17. Jf. Urhistorien, hvor menneskets oprindelige føde består af naturens afgrøder (1 Mos 1,29) og først efter syndfloden suppleres af kød og vin (1 Mos 9,2-4.20). 


\section{Daniel 2,1-49: Drømme om magt og herredømme}

Mens Nebukadnesar i kapitel 1 viste sig ikke at kunne kontrollere oplæringen af de bortførte fra Juda, så kan han i kapitel 2 ikke kontrollere indholdet af sine drømme. Han har haft et urovækkende mareridt, som kun Daniel er i stand til at gengive og tyde. Kongen har i drømmen set, hvordan en stor og frygtindgydende statue i fire dele, et symbol på fire kongeriger, bliver splintret i tusinde stykker ved en overmenneskelig kraft og bliver erstattet af et nyt og evigt kongerige.

Nebukadnesars drøm ligner ved første blik en klassisk hoflegende med en uløselig gåde, konkurrencen mellem hoffets ansatte og ophøjelsen af helten, der som den eneste magter opgaven. En nær parallel finder vi i Josefs tydning af Faraos drømme om køer og korn (1 Mos 41). ${ }^{18}$ Daniel fremstår ligesom Josef som en gudsbenådet drømmetyder, der til slut bliver forfremmet til et af rigets tungeste embeder. Nebukadnesar, den hedenske konge, anerkender tilmed Daniels Gud og priser ham som gudernes Gud, der har magt over historien og kan åbenbare alverdens hemmeligheder. Jøden Daniel har succes i det fremmede, og fortællingen rummer tilsyneladende ikke en egentlig kritik af styret. Det er dog netop i forbindelse med kongens drøm den verden, som kongen ikke selv kan kontrollere - at modstanden viser sig.

Den indledende skildring af hoffet er ikke idylirisk. Det er et sted præget af trusler, misforståelser og farer, for kongens krav til sine rådgivere er skånselsløst. Kan de ikke gengive og udlægge hans drøm, vil alle blive sønderlemmet (jf. 1,10). Som følge af administrationens uduelighed kan kongen slet ikke kontrollere sin vrede. Han befaler opildnet og helt overdrevet, at alle Babylons vismænd bliver slået ihjel. Daniel og hans venner er omfattet af dødsdommen, ikke fordi de er jøder, men fordi de indgår i kongens korps af vise mænd.

Daniels reaktion på truslen om udryddelse er tankevækkende. For det første bruger han sine diplomatiske evner over for Arjok, chefen for kongens livvagt, som har fået til ordre at udføre henrettelserne. Gennem ham får han adgang til kongen og køber sig tid til at kunne tyde drømmen. Han virker så at sige inden for systemet selv i forsøget på at afværge systemets brutalitet. For det andet involverer han straks sine landsmænd, de tre venner, og instruerer dem omsorgsfuldt i at tage del i modstanden mod kongens beslutning. Der er tale om en stærk gruppebevidsthed i det fremmede. Samme solidaritet viser sig til slut, da Daniel deler kongens belønning med de tre og dermed

18. Matthew S. Rindge, "Jewish Identity under Foreign Rule: Daniel 2 as a Reconfiguration of Genesis 41", JBL 129 (2010), 85-104. 
hjælper dem fremad i systemet. For det tredje er svaret på regimets hensynsløshed ikke vold, men bøn. Daniel og vennernes fordybelse i bøn om hjælp er i sig selv et eksempel på, hvor den jødiske diaspora i krisetid må søge støtte og styrke: i hjemlandets religion! Det er åndelig krigsførelse. Gud griber ind, og Daniels lovsang fremhæver en væsentlig pointe, som enhver, der undertrykkes, må klynge sig til: Det er Gud i himlen, som har magten til afsætte og indsætte konger. Og Daniel takker for at have at have fået "visdom og styrke" (v. 23, jf. v. 20). Denne indsigt, denne vidensmagt (ברְּר fortællingen at være det stærkeste våben mod Nebukadnesars ubarmhjertighed (Smith-Christopher 2001, 288).

Daniels samtale med kongen før selve drømmetydningen rummer en subtil kritik af styret. Til indledning havde de babylonske vismænd forsvaret sig med, at Nebukadnesars krav var uhørt. Intet menneske på jorden ville kunne opfylde det, kun guderne i himlen. Det var dette svar, som fremkaldte kongens ustyrlige raseri. $\mathrm{Nu}$ fremfører Daniel samme kritik - kongens krav er urimeligt - men slipper med livet i behold, fordi han i kraft af en himmelsk åbenbaring er i stand til at løse opgaven.

Selve drømmen og tydningen af den indeholder et tvetydigt syn på den babylonske konges magt. På den ene side svarer Nebukadnesar til statuens hoved af det fineste guld. I Daniels udlægning bliver han tiltalt som "kongernes konge" (v. 38), der af Gud har fået et stærkt og indflydelsesrigt kongerige og magt over hele skaberværket. Gud indsætter konger, som Daniel sang. Denne forbløffende positive fremstilling svarer til åbningen af kapitel 1 og Guds overdragelse af ansvaret for Jerusalems skæbne til den hedenske konge. På den anden side udgør Nebukadnesar blot hovedet af en kolossal, men skrøbelig konstruktion. En kolos på lerfødder. Statuens fire kropsdele repræsenterer fire kongeriger, som afløser hinanden på skift, og som et efter et hersker over hele verden. Gud afsætter konger. For statuens udformning afslører også, at verden gennem disse fire epoker bliver mere og mere ustabil. Først kommer guldet, det ædleste metal, så sølvet, så kobberet. $\mathrm{Og}$ til sidst det rå og uædle jern, som tilmed er blandet med det skrøbelige ler. Gradvis bliver verden mere ustabil, gradvis vokser ondskaben og brutaliteten frem. Nebukadnesar har hverken magt over drømmen eller den nye virkelighed, som den foreskriver. Han kan ikke afværge den.

I drømmeverdenen sættes den nuværende og forgængelige virkelighed over for en evig virkelighed. I selve drømmen styrter kolossen nemlig i grus ved et enkelt stenkast. Stenen, der slynges mod statuen, bliver til et bjerg, der strækker sig over hele jorden. I Daniels udlægning er stenen et billede på en virkelighed, hvor Guds eget folk 
regerer. Riget skal ikke gives til et andet folk end jøderne, og de skal tilintetgøre alle de andre riger. Dette rige ligner mere en genoprettelse af Israels fortidige herlighed end et himmelsk evighedsrige og kan afspejle drømme om magt og herredømme hos et underkuet jødisk mindretal under fremmed styre (Newsom 2014, 83).

Inden for Danielsbogens eget univers indbyder afslutningen på drømmen dog til flere fortolkninger. For det første er det en pointe, at stenen, det uforarbejdede naturmateriale, kan knuse kulturens forædling og forarbejdning af jorden og dens metaller. En lignende modstilling mødte vi i kapitel 1 mellem det kongelige måltid og Daniels alternative kost. Sten og bjerg, grøntsager og vand er den "naturlige" og gudsgivne livsfære, som ikke skal fordærves af den babylonske majoritetskultur. For det andet ligger der i drømmen en udlevelse af vold og oprør. I den nuværende verden, i Babylon, må jødernes modstand ske i det skjulte i form af bøn og visdom. Men i drømmen, i foregivelsen af en anden virkelighed, kan mindretallet gribe til våben og nedslagte deres fjender. ${ }^{19}$ For det tredje etableres en parallel mellem drømmen om fremtidigt herredømme og Daniels forfremmelse ved hoffet. De hører begge til fantasiens verden. De er utopier. Drømmen om opnåelse af magt ved et fremmed hof spejler sig i drømmen om et selvstændigt rige, der ikke forgår. Nebukadnesars drøm, som Daniel $i$ et nattesyn gør til sin egen for at kunne gengive og udlægge den (v. 19), er netop en drøm om, at Gud sætter sin magt igennem - og opfylder drømmen også i den virkelige verden.

Efter udlægningen af drømmesynet melder satiren sig igen. Kongens sind er ligeså skrøbeligt som kolossen på lerfødder. Først uforsonlig vred og fjendtlig, nu henrykt og hæmningsløs. Hans pludselige anerkendelse og lovprisning af Daniels Guds almagt cementerer blot hans egen magtesløshed.

Tydningen af Nebukadnesars drøm er altså en blanding af åbenlys succes og underspillet modstand. Daniel fremstår som en engageret og loyal embedsmand, der løser kongens hovedbrud og belønnes behørigt. Men samtidig forudsiger han styrets sammenbrud og beder til, at det må ske. I forlængelse af kapitel 1 spilles to verdener ud mod hinanden. I den ene verden har Nebukadnesar magten, han er indsat af Gud. I den anden verden - i drømmenes verden - er Nebukadnesars dage talte, og han vil sammen med al anden jordisk magt forgå for at skabe plads til den virkelighed, som Gud i himlen skaber for sit undertrykte folk.

19. En lignende fantasi præger voldsorgiet i afslutningen på Esters Bog, hvor jøderne nedslagter deres fjender i titusindvis. 


\section{Daniel 3,1-30: En sag om autoritetstro}

Kapitel 3 beretter om Daniels tre venner, der nægter at tilbede $\mathrm{Ne}$ bukadnesars statue af guld. Som straf kastes de i den glohede ildovn, men reddes mirakuløst af Gud. Fortællingen er en satire, der med barokke og fantasifulde elementer tegner et lattervækkende billede af den hedenske konge og hans forsøg på at bevare magten. På overfladen handler den om en konflikt mellem hoffets forskellige grupperinger, men på et dybere plan behandler den spørgsmålet om loyalitet $\mathrm{i}$ det fremmede. Et dilemma mellem hjemlandets religion og værtslandets krav, som vi også mødte i kapitel 1.

Fortællingen begynder med Nebukadnesars fremstilling af en statue af guld. Rigets ansatte og befolkning indbydes til indvielsesfest med musik og stor ståhej, og alle skal kaste sig ned og tilbede statuen af guld. De, der nægter, skal kastes i ildovnen. Bemærkningen foregriber konfrontationen med Daniels venner om deres manglende deltagelse i den offentlige handling. Men spørgsmålet er, hvad statuen repræsenterer.

Statuens størrelse er i sig selv parodisk. Med en højde på 60 alen (ca. 37 meter) og en bredde på seks alen (ca. 3,7 meter) har den form som en kolossal obelisk. Af guld. Hvis den gengiver en menneskeskikkelse, må vi forestille os dens facon som en af Alberto Giacomettis slanke figurer. På højde med Rundetårn! Det er almindeligt at forstå statuen som et gudebillede, der fremstiller en af Babylons guder. I så fald afspejler vennernes reaktion en modstand mod at dyrke andre guder end deres fædres Gud. Denne læsning understøttes faktisk af statuens mål. I grundplanen over Jerusalems genopbyggede tempel i Ezras Bog, der ligesom denne del af Daniels Bog er skrevet på aramæisk, har bygningen samme højde på 60 alen (Ezra 6,3). ${ }^{20}$ Det er også påfaldende, at ordet for "indvielse" (חִָ i Dan 3,2-3 om statuen og i Ezra 6,16-17 om tempelindvielsen. I Daniels Bog er Jerusalems tempel ødelagt (jf. 1,1-2; 9,17), og i Babylon indvies nu et alternativt tempel, en guderepræsentation, som Nebukadnesar vil tvinge de bortførte til at anerkende. ${ }^{21}$

En anden mulighed er, at statuen forestiller kongen selv. Han har selv lavet og rejst den, i sit eget billede. Samme glose for statue eller billede (צִ̣, șelem) blev i Nebukadnesars drøm brugt om den sta-

20. Jan-Wim Wesselius, "The Writing of Daniel”, The Book of Daniel: Composition and Reception, Volume 2, red. John J. Collins \& Peter W. Flint, VTSup 83,2 (Leiden: Brill 2001), 291-310 (303).

21. Flere af de græske udgaver af Daniels Bog daterer ligefrem begivenheden i kapitel 3 til Nebukadnesars 18. regeringsår, dvs. 587 f.Kr, hvor han indtog Jerusalem og tilintetgjorde dets tempel (jf. Jer 52,29). 
tue, der blev knust (2,31-32.34-35), og dens hoved af guld var som bekendt ham selv $(2,38)$. Læst i forlængelse af kapitel 2 vil Nebukadnesar med opstillingen af guldstatuen undslippe drømmens forudsigelser. ${ }^{22}$ Han forsøger at konsolidere sin magt og styrke riget ved undersåtternes fælles underkastelse. Det er dermed en satirisk pointe, at kongen ikke bare selv må rejse statuen af sig selv, men også selv sikre, at rigets befolkning rent faktisk kommer og kaster sig ned for den. Han må ligefrem true med dødsstraf. Hvis statuen repræsenterer kongen selv, så ligger der i Daniels venners afvisning også en modstand mod hans herredømme. Det tyder det efterfølgende forhør på.

Fra den store offentlige scene zoomes der nu ind på en mindre konflikt mellem hoffets ansatte. Kaldæerne, gruppen af babylonske vismænd, har tilsyneladende holdt øje med Daniels venner i længere tid, måske af misundelse over deres forbløffende fremgang. Her er endelig en mulighed for at få ramt på dem. Man sporer bag hofintrigen også en dybere etnisk konflikt. Da kaldæerne står foran kongen, anklager eller bagtaler de "jøderne" som gruppe. I deres fremstilling taler de om "nogle jødiske mænd”, som er sat til at styre provinsen Babylon, før deres babylonske navne oplistes. Anklagen består af tre dele: manglende opmærksomhed over for kongen, manglende respekt for hans guder og manglende underkastelse for statuen af guld. Det første anklagepunkt bærer mest vægt: Det er Nebukadnesar og hans autoritet, som de udfordrer.

I forhøret truer den flintrende arrige konge de tre jøder med døden. Han spørger retorisk og arrogant: "Hvem er den gud, der kan redde jer ud af min magt?" (v. 15). Ordret står der "ud af mine hænder"

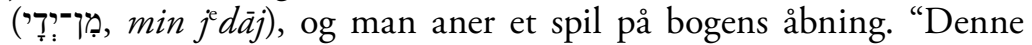
gud" er ingen andre end Gud i himlen, som gav Jerusalem i Nebu-

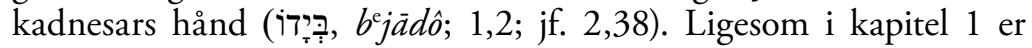
vennerne spændt ud med to verdener, mellem den jordiske konge og den himmelske hersker. Midtpunktet for forhøret er spørgsmålet om loyalitet, og Daniels tre venner udsættes for et ualmindeligt hårdt politisk pres for at indordne sig under kongens magt. Deres svar lader ingen tvivl om, at de er villige til at gå i døden for deres synspunkt. Loyaliteten over for deres fædres Gud er ubetinget, også selvom han måske ikke er stærk nok til at redde dem. De vil ikke underkaste sig. Deres offentlige bekendelse er udtryk for modstand og udstiller, ligesom Daniels bøn og lovsang i kapitel 2, kongens magtesløshed. Han kan tvinge dem ned i ildovnen, men han kan ikke tvinge dem til at tilbede statuen. I åndelige sager har han ingen magt.

22. Greg Goswell, "The Ethics of the Book of Daniel”, ResQ 57 (2015), 129-142 (133). 
Men heller ikke ildovnen har kongen magt over, for flammerne fortærer ikke Daniels venner. De blev bundet, før de blev kastet ned i ovnen, men nu ser kongen dem pludselig gå frit omkring. En fjerde skikkelse er hos dem, en som ser ud som en gud ( ‘lāhîn). Skikkelsen står dermed i modsætning til den gyldne statue, som Nebukadnesar rejste. Den er et synligt og levende symbol på Guds frelsende magt i modsætning til statuen, der stum og ubevægelig blot bekræfter kongens afmagt.

Nebukadnesars afsluttende bekendtgørelse fremhæver ironisk nok de tre jøders trofasthed over for deres Gud. De stolede på ham og brød kongens ord, siger kongen selv. De bliver belønnet og forfremmet, fordi de gjorde modstand! Før blev alle i riget påbudt at kaste sig for statuen af guld. Nu må ingen håne de tre jøders Gud, for ellers skal de miste liv og ejendom.

Fortællingen om de tre venner i ildovnen rummer flere sammenflettede pointer. Den understreger den himmelske Guds magt og afslører derved nytteløsheden i at sætte fremmede guder ved siden af ham. Også under fremmede himmelstrøg. Samtidig behandler den et dilemma ved livet i det fremmede: Hvor går grænsen mellem opretholdelsen af det gamle hjemlands værdier og det nye værtslands krav? I de tre jøders urokkelige loyalitet over for deres fædres Gud ligger en markant afstandtagen til værtslandets magt.

\section{Daniel 3,31-6,1: Himlen er hersker}

Hvor kapitel 3 handler om tre jøders manglende underkastelse for kongens statue, så handler de følgende to kapitler om to kongers manglende underkastelse for Gud. I drømmen om verdenstræet i kapitel 3,31-4,34 straffes Nebukadnesar for sit hovmod, men ydmyger sig og bliver oprejst. I beretningen om skriften på væggen i kapitel 5 ophøjer hans søn, Belshassar, sig også over den himmelske Herre, men straffes med døden. I begge fortællinger handler det om at erkende, at Gud er den egentlige hersker, der kan give sin magt, til hvem han vil $(4,14.22 .29 ; 5,21)$. Gud indsætter konger, Gud afsætter konger, som Daniel tidligere slog fast.

Spændingen mellem loyalitet og modstand, som er løbet som en rød tråd gennem de foregående kapitler, er her koncentreret i Daniels optræden over for værtslandets enehersker. På den ene side er han den hengivne embedsmand og leder af de babylonske vismænd, der bruger sine eminente og gudsgivne evner til at støtte og rådgive kongen. På den anden side er han kritikeren, der taler magten midt imod. 
Over for begge konger består opgaven i at fortolke et varsel i form af en rædselsvækkende drøm og en mystisk indskrift på væggen. Daniel viser i udlægningen af drømmesynet en overraskende medfølelse med Nebukadnesar. Han bliver oprigtigt skræmt over drømmen og ønsker, at den må gælde kongens fjender. Daniel råder ham dernæst til at gøre gode gerninger for - om muligt - at forsinke denne dystre skæbne.

Daniel er anderledes harsk over for sønnen Belshassar. Han afviser udsigten til fyrstelige gaver og anklager strengt kongen for blasfemi mod himlens Herre. Alligevel ender han ironisk nok med at få overrakt værtslandets statussymboler, farverigt tøj, en halskæde af guld og en indflydelsesrig post, som tak for at forudsige kongens snarlige død. Modstanden belønnes, og kongen bliver dræbt samme nat.

Sammenstødet mellem to verdener, den babylonske og den jødiske, blev introduceret i kapitel 1 . Ved åbningen af kapitel 5 viser den sig i modstillingen mellem Guds hus, templet i Jerusalem, og så Belshassars hus, det babylonske festmåltid. Kongen vil ved sit enorme gilde imponere sine gæster ved at drikke vin af de hellige kar. En ting er, at hans far stjal dem og satte dem i et babylonsk tempel. Men nu vil sønnen bruge genstandene til at prise sine egne guder. Selve handlingen har karakter af et overgreb, kulturel appropriation, hvor den babylonske majoritetskultur forsøger at indoptage og udslette en selvstændig tradition. Her den jødiske. Karrene af guld og sølv kan jo ikke gøre modstand; de er blot ting eller symboler på en levende, men truet kultur.

Det er derfor af afgørende betydning, at Daniel, da han føres frem for kongen, præsenteres som "en af de bortførte fra Juda" (v. 13). Han blev ligesom tempelkarrene ført bort fra Jerusalem til et fremmed sted. Han kan gøre modstand. Daniels krasse kritik af Belshassar er derfor også en kritik af den babylonske kultur. For en kultur, som baserer sig på døde ting - på guder i metal, træ og sten, som hverken kan se, høre eller forstå - er dømt til at gå under. Som kongen selv. Festsalen forvandles til en retsal; Belshassars kultur vejes og findes for let. Daniels underforståede modpåstand er derimod, at den kultur, som tempelkarrene repræsenterer, vil overleve. For den baserer sig på Gud, der giver liv. Den levende Gud, som Belshassars efterfølger, Dareios, beskriver ham. 


\section{Daniel 6,2-29: Tro over for Gud og konge}

Kapitel 6 minder om kapitel 3. Daniel bliver ligesom vennerne sat i et skæbnesvangert dilemma mellem religiøs forpligtigelse og en kongelig bestemmelse. Han trues på livet i løvekulen, men udfries mirakuløst ved Guds indgreb. Umiddelbart er pointen, at vedholdenhed i troen belønnes af Gud. Men fortællingen behandler også Daniels eksistens mellem to verdener - Guds og kongens, slægtens religion og værtslandets krav. Og får på en raffineret måde de to verdener til at mødes.

Afsættet er et regeringsskifte i Babylon. Mederen Dareios - en tilsyneladende ren litterær figur - efterfølger den usympatiske Belshassar, og som ved ethvert andet lederskifte indbyder det til positionskamp $i$ magtens centrum. Daniel er én af tre rigsråder, der hersker over rigets 120 administrative enheder, de såkaldte satrapper. Det persiske rige var inddelt i mellem 20 og 30 satrapper, så overdrivelsen her tjener nok til at give et indtryk af et kolossalt stort rige. Som vi har hørt om før, er en usædvanlig ånd i Daniel, der fremhæver ham frem for de andre ansatte ved hoffet. Dareios påtænker ligefrem at tildele den jødiske drømmetyder eneansvaret over hele riget (jf. Josef ved Faraos hof).

Konflikten har ligesom i kapitel 3 karakter af en hofintrige, hvor de øvrige ansatte af jalousi og stræben efter indflydelse prøver at udmanøvrere Daniel. At alle rigsråder og satrapper er imod ham, er en komisk overdrivelse og understreger fortællingens karakter af satire. De kan imidlertid ikke finde noget at anklage ham for, for han er "troværdig" (מְ̣, mênênan), altså pålidelig og loyal over for kongen (v. 5). Udtrykket rummer en dobbelthed, for det kan også pege på hans vedholdenhed i troen; noget, han til slut fremhæves for: han "troede" הירמן, hêmin) på sin Gud (v. 24). Daniels stærke tro er dermed også hans største svaghed, og det er netop her, man vil fælde ham.

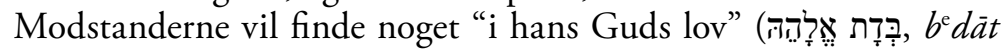
'xäheh), som de kan bruge imod ham. Aggressionen gælder i første omgang ikke hans religion som sådan; den er blot et middel til at ramme ham. De lokker kongen til at forbyde at bede til andre end ham i de næste 30 dage, et forbud som afspejler en pervers ophøjelse af værtslandets magt på bekostningen af rigets mangfoldighed af folk og kulturer (jf. overgrebet på tempelkarrene). Det er dernæst bemærkelsesværdigt, at forbuddet ikke kan ændres "ifølge medernes og

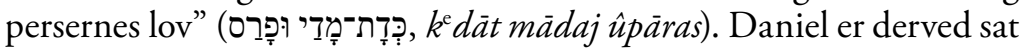
i et uløseligt dilemma mellem to "love" - loyaliteten over for sit oprindelige hjemlands religiøse praksis og værtslandets ultimative krav. 
Daniels overtrædelse sker imidlertid helt bevidst. Da han hører om forbuddet, går han direkte hjem og beder til Gud. På trods. I kapitel 2 bad han i det skjulte; Daniel og vennerne fremstod som en jødisk undergrundsbevægelse, der i al hemmelighed førte åndelig krig mod det babylonske styre. Nu er modstanden anderledes demonstrativ. Den sker ved højlys dag, ved det åbne vindue i husets overetage vendt mod Jerusalem. Denne detalje tegner i første omgang et billede af en from diasporajøde, der tre gange dagligt beder i retning af hjemlandets gamle hovedstad (jf. idealet i Salomos templebøn i 1 Kong 8). Men det åbne vindue er samtidig et udtryk for Daniels synlige og udtalte modstand; han kan ses fra gaden, hans åbenlyse protest og civile ulydighed kan nemt afsløres.

I deres anklage fremhæver hoffolkene Daniels etniske, kulturelle og religiøse baggrund. Han er stadig blot "en af de bortførte fra Juda" (v. 14). Han har ikke været opmærksom på kongen og fulgt hans forbud; han har udfordret den kongelige autoritet (jf. 3,12). Kongens store medfølelse med Daniel og ønske om redning overrasker, men udstiller blot hans egen magtesløshed midt i det absurde bureaukrati. Han har ikke magt til at ændre sine egne beslutninger. Den fatale bestemmelse kan lige så lidt tilbagerulles, som stenen for indgangen til løvegrotten kan rulles væk. Nu er det ikke onde drømme, som frarøver kongen hans nattesøvn, men grublerier over Daniels skæbne blandt løverne.

Ved solopgang styrter kongen hen til løvegrotten for at se, om hans pålidelige embedsmand stadig er i live. Det er han og tilmed uskadt, for Guds engel lukkede munden på de vilde dyr. Daniels begrundelse er interessant: Han er tro over for både Gud og kongen. Et elegant ordspil i v. 23-24 illustrerer, at denne dobbelte loyalitet er skyld i hans redning (jf. Golan 2019, 12-13). Fordi Gud har fundet ham uskyldig ("lutter renhed i mig"), bliver der ikke fundet nogen skader på hans krop. Og fordi han ikke har handlet ondt mod kongen, gjorde løverne ham ikke ondt. Daniel rettede sig ganske vist ikke efter kongens urimelige forbud. Men hans åndelige modstand gjorde jo ikke skade på kongen. Spændingen mellem de to verdener, som Daniel befinder sig $\mathrm{i}$, opløses her med påstanden om, at han ikke spiller de to ud mod hinanden.

Fortællingen slutter som andre før den: Kongen straffer modstanderne og priser Daniels Gud. Ironien i kapitel 6 består i kongens skrivelse til indbyggerne i hele riget. Først påbød han alle at bede til ham alene. $\mathrm{Nu}$ påbydes alle at frygte jødernes Gud, og Daniel har ligesom vennerne fremgang ved kongens hof. 


\section{Diasporaen i Daniels Bog 1-6}

Livet mellem to verdener udtrykker en grundlæggende dobbelthed eller tvetydighed, som også præger fremstillingen af diasporaen som helhed. Årsagen til de fire jøders ophold i det fremmede er på den ene side ulyksalig. Deres fødeby er lagt i grus, og de er ført væk som krigsfanger. På den anden side ankommer de som unge mænd, teenagere, der næppe har forladt hus, kone og børn hjemme og derfor ligesom Josef i Egypten burde være mere åbne over for at slå sig ned og skabe sig et liv i det fremmede (jf. Jer 29,4-7). Hvad de jo til overmål lykkes med.

Forholdet til det oprindelige hjemland er ligeledes tvetydigt. På den ene side handler flere af fortællingerne om at bevare og videreføre hjemlandets traditioner. Det gælder især den underforståede pointe, at man som jøde alene skal prise og bede til sine fædres Gud. Tilknytningen til Jerusalem og den religiøse arv er åbenlys. Det er det sted, man kommer fra, og gennem hele forløbet opretholdes identiteten som bortført fra Juda. På den anden side afspejler fortællingerne intet $ø$ nske om at vende tilbage slægtens oprindelsessted. Livet i diasporaen er blevet et vilkår.

Dobbeltheden viser sig også i forholdet til værtslandet. Hoffet er som opholdssted tvetydigt. Det er berigende og farefuldt på en og samme tid. På den ene side er kongen ikke egentlig anti-jødisk; han er bare utilregnelig. Daniel og hans venners jødiske ophav er kun problematisk, når modstandere $\mathrm{i}$ hofadministrationen kan bruge det imod dem for selv at stå stærkere. På den anden side handler flere af fortællingerne om magthavernes forsøg på at indoptage og opløse den jødiske tradition i den babylonske majoritetskultur. Det er en kulturkamp, hvor de fire jøder på den side anerkender styret som indsat af Gud og på den anden side kritiserer det for at overskride sine grænser.

Der er inden for diasporasamfundet selv, repræsenteret ved Daniel og hans tre venner, en udtalt solidaritet og gruppebevidsthed. Det gælder særligt ved truslen om udryddelse, hvor Daniel først indvier vennerne i den skjulte modstand og siden deler sin belønning fra kongen med dem. Til forskel fra Esters Bog optræder de fire jøder dog ikke som ledere for det jødiske samfund som sådan. ${ }^{23}$ Der er ingen menighed og ingen fester i Daniels Bog 1-6. Samhørighedsfølelsen er tværtimod udtrykt gennem individuel fromhed, hvor karaktererne

23. I kapitel 9 fremstår Daniel derimod som en lederskikkelse blandt diasporajøderne, der i det fremmede studerer hjemlandets religiøse tekster og beder indtrængende for genopbygningen af det ødelagte hjemland; se Frederik Poulsen, "Daniel's Prayer for Jerusalem: Reading Daniel 9 in a Diaspora Context", SJOT 35 (under udgivelse). 
hver for sig fordyber sig i jødisk fromhedspraksis. Det er dog muligt, at disse enkeltskæbner netop repræsenterer fælleskabet som helhed, og at deres kamp symboliserer fællesskabets kamp for social overlevelse i det fremmede.

Diasporatilværelsen mellem to verdener, det oprindelige hjemland og det nye værtsland, i første halvdel af Daniels Bog svarer til tilværelsen mellem himmel og jord i bogens anden halvdel. Den afsky over for værtskulturen og dens overgreb, som man aner i kapitel 1-6, overføres i kapitel 7-12 på den jordiske virkelighed som helhed. Den er brutal og forløjet, men i sidste ende skrøbelig og kan væltes omkuld af Gud. Følelsen af fremmedgørelse over for den foreliggende verden og påstanden om en alternativ, overjordisk virkelighed er et stærkt motiv i den apokalyptiske litteratur. Bogens to halvdele spejler sig dermed i hinanden og skaber en tematisk sammenhæng i bogen som helhed: Daniel mellem to verdener. 